\title{
Renal and hepatic distribution of type I and type III iodothyronine deiodinase protein in chicken
}

\author{
C H J Verhoelst, S Van der Geyten and V M Darras \\ Laboratory of Comparative Endocrinology, Zoological Institute, Naamsestraat 61, B-3000 Leuven, Belgium \\ (Requests for offprints should be addressed to C H J Verhoelst; Email: Carla.Verhoelst@bio.kuleuven.ac.be)
}

\begin{abstract}
Iodothyronine deiodinase in vitro activity studies in the chicken showed the presence of type I and type III iodothyronine deiodinase activity in both liver and kidney. Due to the lack of a specific antiserum the cellular localization of the deiodinase proteins could not be revealed until now. In the present study, specific antisera were used to study the renal and hepatic distribution of type I and type III iodothyronine deiodinase protein in the chicken. Immunocytochemical staining of liver tissue led to an immunopositive signal in the hepatocytes in general. Moreover, a zonal distribution could be detected for both enzymes. Maximum protein expression was shown in a thin layer of hepatocytes bordering the blood veins.
\end{abstract}

Although pericentral localization of type I deiodinase protein has been previously reported in the rat, no data were given concerning type III deiodinase protein. In the present study, we report the co-localization of both enzymes in the chicken. Co-expression of the deiodinases was also found in the kidney. Expression of both proteins was associated with the tubular epithelial cells and with the transitional epithelium, and the inner longitudinal and outer circular muscle layers of the ureter. No staining could be detected in the lamina propria or in the fat tissue surrounding the ureter.

Journal of Endocrinology (2004) 181, 85-90

\section{Introduction}

In most vertebrates, the thyroid gland mainly secretes the relatively inactive prohormone, thyroxine. By means of a process called outer ring deiodination this prohormone is converted into its active form, namely 3,5,3'-triiodothyronine $\left(\mathrm{T}_{3}\right) \cdot \mathrm{T}_{3}$ can be degraded into an inactive hormone, 3,3'-di-iodothyronine, by means of inner ring deiodination (Visser 1990). The enzymes responsible for these reactions are the iodothyronine deiodinases. Three different deiodinases have been characterized, namely type I, type II and type III deiodinase. Type I deiodinase is able to exert both outer and inner ring deiodination, while type II and type III deiodinase only catalyse outer or inner ring deiodination respectively. Deiodinases are selenoproteins, containing the rare amino acid selenocysteine in their active site (St Germain \& Galton 1997). The cloning of the first deiodinase cDNA in the rat by Berry et al. (1991) led to a very rapid revelation of deiodinase sequences in other species such as the human (Mandel et al. 1992, Salvatore et al. 1995, 1996), the mouse (Maia et al. 1995), the dog (Toyoda et al. 1995), the chicken (Van der Geyten et al. 1997, Gereben et al. 1999), tilapia (Lee et al. 1993, Sanders et al. 1997, 1999), Rana catesbeiana (Becker et al. 1995, Davey et al. 1995) and Xenopus laevis (St Germain et al. 1994).
Although the in vitro deiodinase activities as well as the tissue-related expression of the deiodinases have been studied extensively (Darras et al. 1992, Bates et al. 1999, Van der Geyten et al. 2002), little is known about the cellular distribution of the enzymes within a given tissue because of the lack of good antisera. Only within the past 2 years some reports become available on the use of antisera in iodothyronine deiodinase protein localization studies. Zandieh Doulabi et al. (2002) showed that, in the rat, hepatic type I deiodinase protein is associated with the hepatocytes that circumscribe the central blood veins. They found a co-localization of the enzyme with the thyroid hormone receptor isoform $\beta 1$. Our group (Verhoelst et al. 2002) demonstrated the presence of type III deiodinase in the Purkinje cells of the chicken cerebellum. This was the first report on the presence of a deiodinase protein in a neuronal cell type. Just recently, Diano et al. (2003) described the localization of rat type II deiodinase immunolabelled cells in the hypothalamus. The strongest signal was found in the arcuate nucleus/median eminence and in the periventricular region of the third ventricle.

Since the few immunocytochemical data on iodothyronine deiodinase proteins are mostly limited to the brain, except for the study of Zandieh Doulabi et al. (2002), the present work was performed to reveal protein expression 
patterns in some peripheral tissues, namely the liver and the kidney, since these are known to contain relatively high deiodinase activities.

\section{Materials and Methods}

\section{Polyclonal antisera}

For the production of polyclonal antisera against type I (D1) and type III iodothyronine deiodinase (D3), specific synthetic peptides were chosen to consider the hydropathy profile of the entire chicken enzyme amino acid sequence: D1 peptide $\left(\mathrm{NH}_{2}-(235)\right.$ YHPQEIRAVLEKLK(250)$\mathrm{COOH})$ and $\mathrm{D} 3$ peptide $\left(\mathrm{NH}_{2}-(41)\right.$ TAGEGPPPDDP $\mathrm{PV}(53)-\mathrm{COOH})$. New Zealand White rabbits were injected every 3 weeks with the conjugates (D1 - keyhole limpet haemocyanine; D3 - bovine serum albumin). The serum was collected, snap frozen in a mixture of dry ice and ethanol and stored at $-80{ }^{\circ} \mathrm{C}$ until further use. For a detailed description of the specificity tests of the antisera, see the previously published manuscripts from our group. Possible cross-reactivity between the deiodinases was tested for all antisera used. Furthermore, blocking experiments were carried out using the exhausted primary antiserum (Verhoelst et al. 2002, 2004).

\section{Tissue collection and fixation}

Eighteen-day-old chicken embryos (E18) were killed and liver and kidney tissue was fixed in Bouin-Hollande solution for $24 \mathrm{~h}$. Tissues were washed thereafter for $24 \mathrm{~h}$ using running tap water. Before paraffin embedding the following incubation steps were performed: $50 \% \mathrm{EtOH}$ (2 h), 70\% EtOH (2 h), 95\% EtOH (2 h), 100\% EtOH (overnight), 1:1 EtOH:xylol (4 h), 100\% xylol (4 h), 100\% xylol (overnight), 1:1 xylol:paraffin $(4 \mathrm{~h}), 100 \%$ paraffin (4 h), 100\% paraffin (overnight). Paraffin slices of $7 \mu \mathrm{m}$ thickness were cut using a historange CBK microtome Bromma 2218. The slices were always dried for minimum $72 \mathrm{~h}$ prior to use in immunocytochemical applications.

In a second experiment, E18 chicks were injected i.v. with $50 \mu \mathrm{g}$ dexamethasone (DEX) or saline. Four hours later the chicken embryos were killed and liver and kidney samples were taken for immunocytochemistry as described above. In addition, liver samples were frozen in liquid nitrogen for use in an in vitro kinetic activity study and Western blot analysis.

\section{Immunocytochemistry}

The paraffin slices were hydrated by means of 100\% xylol (twice, $15 \mathrm{~min}$ each time), 96\% EtOH (3 min), 90\% $\mathrm{EtOH}(3 \mathrm{~min}), 80 \% \mathrm{EtOH}(3 \mathrm{~min}), 70 \% \mathrm{EtOH}(3 \mathrm{~min})$ and washed in distilled water for $10 \mathrm{~s}$. Blocking buffer $(5 \%$ low fat milk in Tris-buffered saline (TBS) containing 0.5\%
Triton X-100 (TBST)) was then applied for $1 \mathrm{~h}$ at room temperature to block all non-specific binding sites. The slices were then incubated with the primary antiserum diluted 1:100 in blocking buffer for $1 \mathrm{~h}$ at room temperature and overnight at $4{ }^{\circ} \mathrm{C}$. Next, the slices were washed twice with TBST at room temperature. Alkaline phosphate (AP)-linked goat-anti rabbit immunoglobulins were applied subsequently for $1 \mathrm{~h}$ at room temperature (1:250 in TBST). Finally, the slices were washed twice with TBS (10 min each wash) and twice with AP ( $\mathrm{pH} 9 \cdot 5)$ buffer (10 min each wash). Then the detection reagent (nitro blue tetrazolium/5-bromo-4-chloro-3-indolyl-phosphate) was applied for 45-60 min. The slices were washed with $\mathrm{MeOH}$ and enclosed with chomoglycerin.

\section{In vitro $D 3$ activity analysis}

In vitro D3 activity measurements were performed in optimal conditions for the respective enzyme on liver microsomal fractions (method described by Van der Geyten et al. 2001). In short, incubation mixtures contained 150000 c.p.m. $\left[3^{\prime}-{ }^{125} \mathrm{I}\right] \mathrm{T}_{3}, 10 \mathrm{nM} \mathrm{T}, 1 \mu \mathrm{M}$ reverse $\mathrm{T}_{3}, 50 \mu \mathrm{g}$ protein/ml, $0 \cdot 1 \mathrm{mM}$ PTU 6-propyl-2thiouracil and $50 \mathrm{mM}$ dithiothreitol in sodium phosphate buffer ( $\mathrm{pH} 7 \cdot 2$ ) and $2 \mathrm{mM}$ EDTA. Reaction products were analysed by HPLC (Eelkman-Rooda et al. 1989). Incubation was stopped by the addition of $300 \mu \mathrm{l}$ ice-cold methanol. After centrifugation $(3500 \mathrm{~g}, 10 \mathrm{~min}), 200 \mu \mathrm{l}$ supernatant aliquots were transferred to vials containing $250 \mu \mathrm{l}$ ammonium acetate $(0 \cdot 02 \mathrm{M}, \mathrm{pH} 4 \cdot 0)$. Labelled iodothyronines and $\mathrm{I}^{-}$were separated by injection of $80 \mu \mathrm{l}$ of this mixture onto a C18 column (Nucleosil 100-5 C18; Filter Service, Eupen, Belgium) and elution with a $47 / 53 \%(\mathrm{v} / \mathrm{v})$ mixture of methanol and ammonium acetate buffer at a flow rate of $1 \mathrm{ml} / \mathrm{min}$. Radioactivity was assessed with an on-line radioactivity monitor (LB 506 C-1; Perkin Elmer, Norwalk, CT, USA), and peaks were integrated using the winflow program (JBMS, Grenoble, France). All activities were calculated as the amount of substrate deiodinated/mg protein per min.

\section{ECL Western analysis}

Starting from $250 \mathrm{mg}$ liver (saline- versus DEX-treated animals), hepatic membrane proteins were separated from the soluble protein fraction using the proteoprep universal extraction kit (Sigma). Protein concentrations were determined according to the method of Bradford (1976). Samples were diluted to a final concentration of $7 \mathrm{mg} / \mathrm{ml}$ in distilled water. Laemmli buffer was added in a 1:3 ratio. Ten microlitres of sample were loaded onto a $12.5 \%$ acrylamide/bisacrylamide gel. After electrophoresis, the gels were blotted onto a PVDF membrane. The D3 antiserum was added in a dilution of 1:100. The secondary antibody (GAR-HRP) was used in a dilution of 1:1000. Detection of the antiserum occurred using the ECL Western blotting detection system of Amersham 


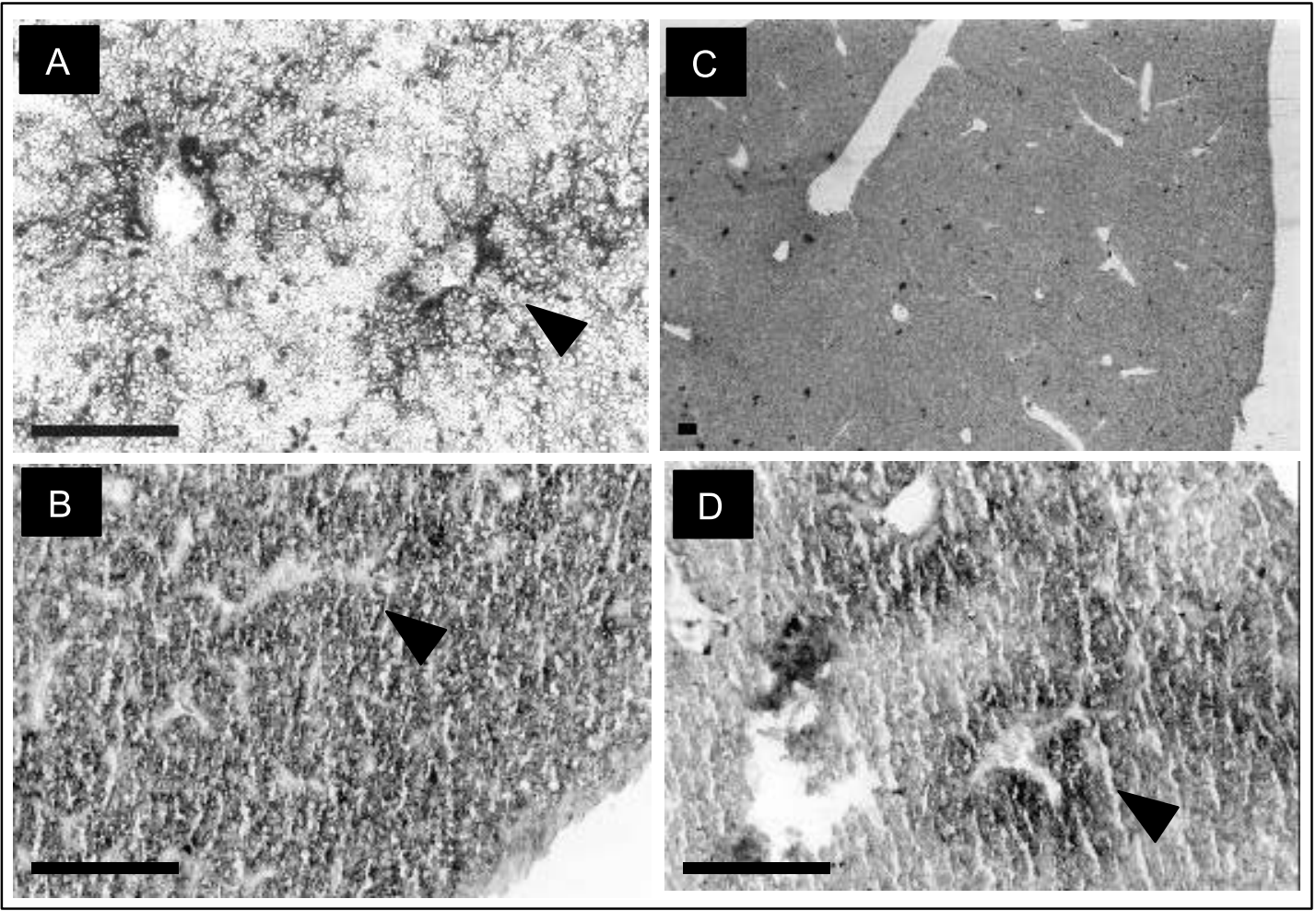

Figure 1 AP staining of paraffin slices of E18 chicken liver (A) with type I deiodinase antiserum, (B) with type III deiodinase antiserum (saline), (C) with preimmune serum and (D) with type III deiodinase antiserum (DEX). Arrowheads indicate blood vessels. The black bars represent $100 \mu \mathrm{m}$.

Pharmacia Biotech. The blots were exposed to an autoradiographic Hyper ECL film and exposed for approximately $10 \mathrm{~s}$.

All experimental procedures were approved by the Katholieke Universiteit Leuven ethical experimental animal committee.

\section{Results}

As shown in Fig. 1A hepatocytes were stained using the type I deiodinase antiserum. Although overall staining of the liver was found, a very strong signal could be detected in the epithelial cells around the hepatic blood vessels in general. Figure 1C represents one of the negative controls, namely incubation with preimmune serum. Clearly, no immunopositive cells were detected in the latter. For D3, the overall staining of the hepatocytes seemed to be much more intense. Therefore, the staining pattern around the blood veins was not as local as for D1, but was nevertheless present (Fig. 1B). The hepatic distribution for DEXtreated animals is shown in Fig. 1D. It can be seen that in this case D3 protein expression is restricted to the area circumscribing the blood vessels, comparable with D1 protein expression. D3 activity levels and Western blot analysis are represented in Fig. 2. DEX-treated chicken

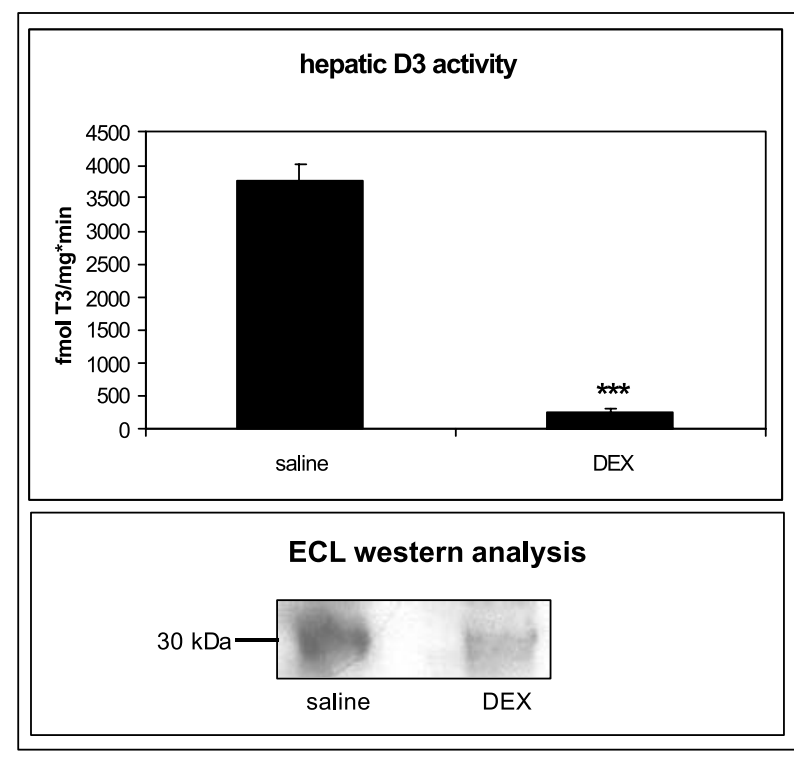

Figure 2 (A) In vitro D3 activity ( $\mathrm{fmol}_{3} / \mathrm{min}$ per $\mathrm{mg}$ protein) of control (saline) and DEX-treated chicken E18 liver. Data presented are means \pm S.E.M. $(n=8) .{ }^{* *} P<0 \cdot 001$ (Student's $t$-test). (B) ECL Western analysis of control (saline) and DEX-treated chicken E18 liver. 


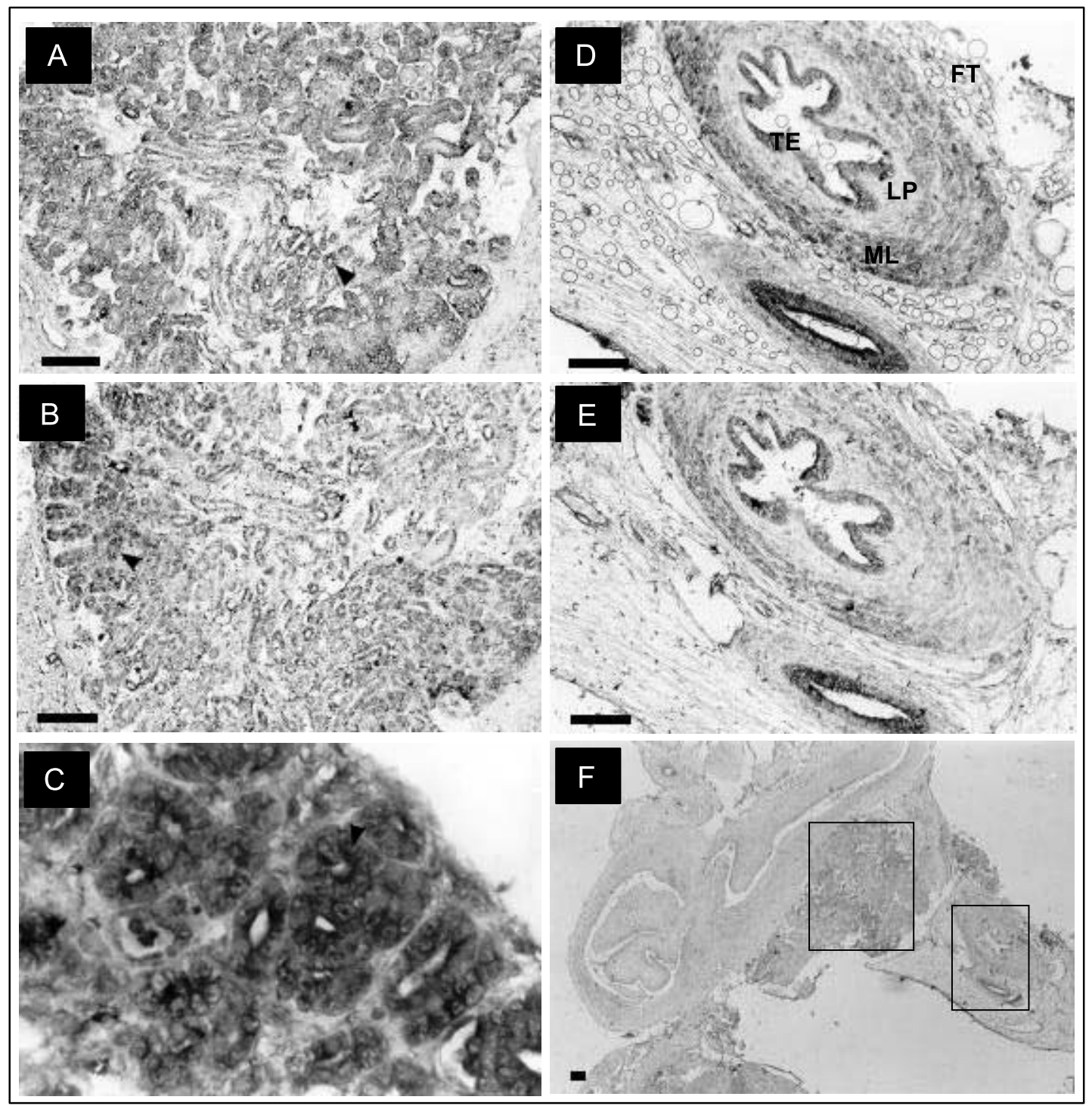

Figure 3 AP staining of paraffin slices of E18 chicken kidney. (A) Detail of the renal cortex with the tubuli stained with type I deiodinase antiserum, (B) detail of the renal cortex with the tubuli stained with type III deiodinase antiserum, (C) detail of tubuli stained with type III deiodinase antiserum, (D) detail of the ureter stained with type I deiodinase antiserum, (E) detail of the ureter stained with type III deiodinase antiserum and (F) overview of the kidney slice incubated with preimmune serum. TE, transitional epithelium; LP, lamina propria; ML, muscle layer; FT, fat tissue. Arrowheads indicate tubules. The black bars represent $100 \mu \mathrm{m}$. Black boxes indicate enlarged areas in A, B, D and F.

embryos showed a significantly lower D3 activity level when compared with saline-injected animals $(P<0 \cdot 001)$. Furthermore, the D3 protein expression itself was decreased in these animals as was determined by Western analysis. The $30 \mathrm{kDa}$ band representing the D3 enzyme showed a much lower intensity than that of control chicks.

Immunocytochemistry performed on kidney tissue revealed staining of the tubular epithelial cells for both D1 and D3 protein (Fig. 3A and B). Figure 3C represents a detail of the tubuli stained with anti-D3. Furthermore, a very clear positive result was found in the ureter with both antisera. Figure $3 \mathrm{D}$ and $\mathrm{E}$ represent the staining of the ureter for D1 and D3 respectively. In both cases, the transitional epithelium as well as the inner longitudinal and the outer circular muscle layer of the ureter were stained. No staining was found in the lamina propria or in the fat tissue surrounding the ureter. Figure $3 \mathrm{~F}$ represents an overview of tissue slices incubated with preimmune serum instead of primary antiserum. The negative control remained blank. 


\section{Discussion}

In the present report we describe the co-localization of D1 and D3 protein in liver and kidney. Renal and hepatic D1 and D3 activity have been extensively studied in the past, but only a few data are available on the distribution of the deiodinase proteins in general. Bates et al. (1999) previously showed the co-expression of D3 mRNA, together with D1 and D2 mRNA in several rat tissues. The fact that the enzymes tend to be expressed in the same tissue suggests the need to tightly regulate the intracellular $T_{3}$ levels within these tissues at certain critical stages in development. The co-expression that Bates et al. (1999) found was similar to earlier published results in tadpoles at the point of metamorphosis (Becker et al. 1995).

During the last week of embryonic development the chicken embryo displays a high hepatic D1 activity, whereas the D3 activity is very high until days 18-19 and decreases by 100 -fold thereafter. These changes explain the strong increase in plasma $T_{3}$ on E20, which is the point at which the embryo switches to lung respiration (Darras et al. 1992, Van der Geyten et al. 1997). The current study describes the presence of D1 and D3 protein in the hepatocytes in general with a maximal expression of the enzymes around the central blood veins, especially in the case of D1. For D3 deiodinase we suggest that, given the data on enzyme activity, the amount of protein is so high on day 18 of embryonic development that no difference can be seen at this stage between the hepatocytes in general and those surrounding the blood vessels. Zandieh Doulabi et al. (2002) recently reported on the presence of D1 protein in rat liver. They described a preferential pericentral expression of both the thyroid hormone receptor $\beta 1$ and D1. The expression of both proteins decreased from the pericentral zone towards the periportal zone. A comparable zonal distribution pattern seems to be present in the chicken, although portal and central blood vessel markers should be used to confirm this. However, the expression of D1 protein follows the same pattern as does rat D1 with regard to the fading of the signal outwards from the blood vessel. As explained earlier, the same might be true for D3 protein but, due to the relatively high signal throughout the whole liver, no difference could be seen between the hepatocytes surrounding the blood vessels and other hepatocytes. Comparison of DEX-treated and control chickens, however, made it possible to elucidate this matter. DEX is known to be related to a fall in $T_{3}$ breakdown in the liver by down-regulation of the D3 (Van der Geyten et al. 2001). This study has confirmed that a reduction in hepatic D3 enzyme activity is accompanied by a decrease in protein expression in the hepatocytes as was detected by immunocytochemistry. The D3 enzyme staining only remained constant where the expression of the protein was the highest, namely in the hepatocytes surrounding the blood vessels. Western blot analysis confirmed the hepatic D3 enzyme down-regulation after DEX administration. The high expression of the deiodinase proteins around the blood vessels again highlights the importance of a wellworking regulation mechanism to maintain homeostasis in the intracellular and plasma $\mathrm{T}_{3}$ levels. Given their localization, the deiodinases are not only able to comply with the intracellular need for active thyroid hormone, but $\mathrm{T}_{3}$ can also be easily transported through the blood circulation. Furthermore, local action of active $T_{3}$ is suggested, given the presence of thyroid hormone receptor pericentrally as found in the rat.

With regard to the kidney, Van der Geyten et al. (2002) recently reported the differential expression of iodothyronine deiodinases in chicken tissues during the last week of embryonic development. In kidney, D1 and D3 activity and mRNA are both present during the last week of development and they both gradually increase towards hatching. Taking into account the high expression of D1 in kidney, the authors suggest that it is very unlikely that D3, given its relatively low activity levels, plays a major role in the regulation of the renal $\mathrm{T}_{3}$ exported to plasma. However, considering the fact that D3 protein expression might be limited to a specific cell type, it might play a role in regulating the intracellular $\mathrm{T}_{3}$ levels that are optimal for tissue development. We have described the expression of D1 and D3 in renal tubuli and several layers of the ureter. Leonard et al. (1991) performed affinity labelling and catalytic activity studies to determine the regional distribution of D1 in rat kidney. They also found D1 activity in the tubular epithelial cells of the outer renal cortex. Lee et al. (1993) also reported the presence of D1 mRNA in the rat kidney tubuli. Given the fact that the source of the substrate for both D1 and D3 is the circulation, finding their distribution pattern in close proximity to blood reservoirs was expected. The presence of D1 and D3 in the ureter could be related to development. Thyroid hormones play a crucial role in the regulation of different developmental processes. They are important for growth in general, thermogenesis, and several metabolic and differentiation processes (Decuypere et al. 1990, Beckett \& Arthur 1994). Therefore the presence of D1 and D3 in the ureter may be associated with the local provision of the essential levels of active thyroid hormone needed for development. Localization of the deiodinases in the tubuli, on the other hand, might rather be related to the distribution of the thyroid hormones towards the renal cells for appropriate differentiation of these cells at this stage. Further comparative studies between embryonic and post-hatch chickens should be performed to confirm this.

In conclusion, this study showed the distribution of D1 and D3 deiodinase protein in the chicken liver and kidney. In accordance with previous results in the rat, D1 could be detected in hepatocytes in general and the expression pattern was most intense in the area surrounding the blood vessels. For D3, a very strong staining was found throughout the whole liver. Comparison of DEX-treated animals 
with control animals revealed that the D3 protein showed the same distribution as does D1 when it is downregulated. In the kidney, again co-localization of both enzymes was found in the epithelial cells of the renal tubuli and in several layers of the ureter. Comparison of the staining signals for both deiodinases strongly suggests that they are indeed expressed in the same cell type, although this may need additional confirmation.

\section{Acknowledgements}

We wish to thank Willy Van Ham, Francine Voets, Lut Noterdaeme and Tina Everaert for their valuable technical assistance.

\section{Funding}

This work was supported by the Katholieke Universiteit Leuven Research Council Grant OT-01-23, Fonds voor Wetenschappelijk Onderzoek Vlaanderen Grant G.O272.04 and European Union Grant QLG3-CT200000930. Serge Van der Geyten was supported by the Fund for Scientific Research, Flanders, Belgium.

\section{References}

Bates JM, St Germain DL \& Galton VA 1999 Expression profiles of the three iodothyronine deiodinases D1, D2 and D3, in the developing rat. Endocrinology 140 844-851.

Becker KB, Schneider MJ, Davey JC \& Galton VA 1995 The type III $5^{\prime}$-deiodinase in Rana catesbeiana tadpoles is encoded by a thyroid hormone-responsive gene. Endocrinology 136 4424-4431.

Beckett CJ \& Arthur JR 1994 The iodothyronine deiodinases and $5^{\prime}$ deiodination. Bailliere Clinical Endocrinology and Metabolism 8 285-304.

Berry MJ, Banu L \& Larsen PR 1991 Type I iodothyronine deiodinase is a selenocysteine-containing enzyme. Nature 349 438-440.

Bradford MM 1976 A rapid and sensitive method for the quantitation of microgram quantities of protein utilizing the principle of protein-dye binding. Analytical Biochemistry 72 248-254.

Darras VM, Visser TJ, Berghman LR \& Kühn ER 1992 Ontogeny of type I and type III iodothyronine deiodinase activities in embryonic and posthatch chicks: relationship with changes in plasma triiodothyronine and growth hormone levels. Comparative Biochemistry and Physiology 103A 131-136.

Davey JC, Becker KB, Schneider MJ, St Germain DL \& Galton VA 1995 Cloning of a cDNA for the type II iodothyronine deiodinase. Journal of Biological Chemistry 270 26786-26789.

Decuypere E, Dewil E \& Kühn ER 1990 The hatching process and the role of hormones. In Avian Incubation, pp 239-256. Ed. SC Tullett. London: Butterworths.

Diano S, Leonard JL, Meli R, Esposito E \& Schiavo L 2003 Hypothalamic type II iodothyronine deiodinase: a light and electron microscopy study. Brain Research 976 130-134.

Eelkman-Rooda SJ, Otten MH, van Loon MAC, Kaptein E \& Visser TJ 1989 Metabolism of triiodothyronine in rat hepatocytes. Endocrinology 125 2187-2197.

Gereben B, Bartha T, Tu HM, Rudas P \& Larsen PR 1999 Cloning and expression of the chicken type II iodothyronine $5^{\prime}$-deiodinase. Journal of Biological Chemistry 274 13768-13776.

Lee WS, Berry MJ, Hediger MA \& Larsen PR 1993 The type I iodothyronine $5^{\prime}$-deiodinase messenger ribonucleic acid is localized to the S3 segment of the rat kidney proximal tubule. Endocrinology 132 2136-2140.
Leonard JL, Ekenbarger DM, Frank SJ, Farwell AP \& Koerle J 1991 Localization of type I iodothyronine $5^{\prime}$-deiodinase to the basolateral plasma membrane in renal cortical epithelial cells. Journal of Biological Chemistry 266 11262-11269.

Maia AL, Berry MJ, Sabbag R, Harney JW \& Larsen PR 1995 Structural and functional differences in the diol gene in mice with inherited type I deiodinase deficiency. Molecular Endocrinology 9 969-980.

Mandel SJ, Berry MJ, Kieffer JD, Harney JW, Warne RL \& Larsen PR 1992 Cloning and in vitro expression of the human selenoprotein, type I iodothyronine deiodinase. Journal of Clinical Endocrinology and Metabolism 75 1133-1139.

St Germain DL \& Galton VA 1997 The deiodinase family of selenoproteins. Thyroid 7 655-668.

St Germain DL, Schwartzman RA, Croteau W, Kanamori A, Wang Z, Brown DD \& Galton VA 1994 A thyroid hormone-regulated gene in Xenopus laevis encodes a type III iodothyronine deiodinase. PNAS 91 7767-7771.

Salvatore D, Low SC, Berry MJ, Maia AL, Harney JW, Croteau W, St Germain DL \& Larsen PR 1995 Type 3 iodothyronine deiodinase: cloning, in vitro expression, and functional analysis of the placental selenoenzyme. Journal of Clinical Investigation 96 2421-2430.

Salvatore D, Bartha T, Harney JW \& Larsen PR 1996 Molecular biological and biochemical characterization of the human type 2 selenodeiodinase. Endocrinology 137 3308-3315.

Sanders JP, Van der Geyten S, Kaptein E, Darras VM, Kühn ER, Leonard JL \& Visser TJ 1997 Characterization of a propylthiouracil-insensitive type I iodothyronine deiodinase. Endocrinology 138 5153-5160.

Sanders JP, Van der Geyten S, Kaptein E, Darras VM, Kühn ER, Leonard JL \& Visser TJ 1999 Cloning and characterization of type III iodothyronine deiodinase from the fish Oreochomis niloticus. Endocrinology 140 3666-3673.

Toyoda N, Harney JW, Berry MJ \& Larsen PR 1995 Identification of critical amino acids for $3,3^{\prime}, 5^{\prime}$-triiodothyronine deiodination by human type I deiodinase based on comparative functional-structural analyses of the human, dog and rat enzymes. Journal of Biological Chemistry $26920329-20344$.

Van der Geyten S, Sanders JP, Kaptein E, Darras VM, Kühn ER, Leonard JL \& Visser TJ 1997 Expression of chicken hepatic type I and type III iodothyronine deiodinase during embryonic development. Endocrinology 138 5144-5152.

Van der Geyten S, Segers I, Gereben B, Bartha T, Rudas P, Larsen PR, Kühn ER \& Darras VM 2001 Transcriptional regulation of iodothyronine deiodinases during embryonic development. Molecular and Cellular Endocrinology 183 1-9.

Van der Geyten S, Van den Eynde I, Segers IB, Kühn ER \& Darras VM 2002 Differential expression of iodothyronine deiodinases in chicken tissues during the last week of embryonic development. General and Comparative Endocrinology 128 65-73.

Verhoelst CHJ, Vandenborne K, Severi T, Bakker O, Zandieh Doulabi B, Leonard JL, Kühn ER, Van der Geyten S \& Darras VM 2002 Specific detection of type III iodothyronine deiodinase protein in chicken cerebellar Purkinje cells. Endocrinology 143 2700-2707.

Verhoelst CHJ, Darras VM, Zandieh Doulabi B, Reyns G, Kühn ER \& Van der Geyten S 2004 Type I iodothyronine deiodinase in euthyroid and hypothyroid chicken cerebellum. Molecular and Cellular Endocrinology 214 97-105.

Visser TJ 1990 Importance of deiodination and conjugation in the hepatic metabolism of thyroid hormone. In The Thyroid Gland, pp 255-283. Ed. MA Greer. New York: Raven Press.

Zandieh Doulabi B, Platvoet-ter Schiphorst M, van Beeren HC, Labruyere WT, Lamers WH, Fliers E, Bakker O \& Wiersinga WM 2002 TR $\beta 1$ protein is preferentially expressed in the pericentral zone of rat liver and exhibits marked diurnal variation. Endocrinology 143 979-984.

Received 18 December 2003

Accepted 21 January 2004 